\title{
Erratum to: Ethical Dimensions of Muslim Education
}

\section{Erratum to:}

(C) The Editor(s) (if applicable) and The Author(s) 2016

N. Davids, Y. Waghid, Ethical Dimensions of Muslim Education, DOI 10.1007/978-3-319-29317-2

The original version of the FM of this book contained errors which have been corrected in the updated version. The corrections are given below:

Nuraan Davids • Yusef Waghid

Department of Education Policy Studies, Faculty of Education, Stellenbosch University, Cape Town, South Africa

List of Surahs (Chapters) and Their English Translations in Brackets

1. Al-Fatihah (The Opening)

2. Al-Baqarah (The Cow)

3. Al-Imrān (The Family of Amran)

4. An-Nisā' (The Women)

5. $A l-M \bar{a}$ 'dah (The Food)

6. $A l-A n^{\prime}-\bar{a} m$ (The Cattle)

The updated original online version for this book can be found at DOI 10.1007/978-3-319-29317-2.

(C) The Editor(s) (if applicable) and The Author(s) 2016 El

N. Davids, Y. Waghid, Ethical Dimensions of Muslim Education, DOI 10.1007/978-3-319-29317-2_13 
7. Al-'A'rāf (The Elevated Places)

8. Al-Anfāl (Voluntary Gifts)

9. Al-Barā'at/At-Taubah (The Immunity)

10. Yünus (Jonah)

11. Hūd (Hud)

12. Yūsuf (Joseph)

13. Al-R $\bar{a} d$ (The Thunder)

14. Ibrā hìm (Abraham)

15. Al-Hijr (The Rock)

16. An-Nabl (The Bee)

17. Bani Isrāil (The Israelites)

18. Al-Kahf (The Cave)

19. Maryam (Mary)

20. Tā $H \bar{a}$ (Ta Ha)

21. Al-'Anbiyā' (The Prophets)

22. Al-Hajj (The Pilgrimage)

23. Al-Muminūn (The Believers)

24. An-Nūr (The Light)

25. Al-Furqān (The Discrimination)

26. Al-Shu'arā' (The Poets)

27. An-Naml (The Naml)

28. Al-Qasas (The Narrative)

29. Al-Ankabūt (The Spider)

30. Ar-Rūm (The Romans)

31. Luqmān (Luqman)

32. As-Sajdah (The Adoration)

33. Al-Abzāb (The Allies)

34. Al-Sabā' (The Saba)

35. Al-Fātir (The Originator)

36. $\operatorname{răsin}($ Ya Sin)

37. As-Saffāt (Those Ranging in Ranks)

38. $\quad \operatorname{Sād}(\mathrm{Sad})$

39. Az-Zumar (The Companies)

40. Al-Mu'min (The Believer)

41. Hāmìm (Ha Mim)

42. As-Shūrā (Counsel)

43. Az-Zukhruf (Gold)

44. Ad-Dukkbān (The Drought)

45. Al-Jāthiyah (The Kneeling) 
46. Al-Ahqāf (The Sandhills)

47. Mubammad (Muhammad)

48. Al-Fath (The Victory)

49. Al-Hujjarāt (The Apartments)

50. $Q \bar{\alpha} f(\mathrm{Qaf})$

51. Ad-Dhāriyāt (The Scatterers)

52. At-Tūr (The Mountain)

53. An-Najm (The Star)

54. Al-Qamar (The Moon)

55. Ar-Rabmān (The Beneficent)

56. Al-Wāqi'ah (The Event)

57. Al-Hadid (Iron)

58. Al-Mujādilah (The Pleading Woman)

59. Al-Hashr (The Banishment)

60. Al-Mumtabinah (The Woman who is Examined)

61. As-Saff (The Ranks)

62. Al-Jumu'ah (The Congregation)

63. Al-Munāfiqūn (The Hypocrites)

64. At-Taghāfbun (The Manifestation of Losses)

65. At-Talāq (Divorce)

66. At-Tahrim (The Prohibition)

67. Al-Mulk (The Kingdom)

68. Al-Qalam (The Pen)

69. Al-Hāqqah (The Sure Truth)

70. Al-Ma'ārij (The Ways of Ascent)

71. Nüh (Noah)

72. Al-Jinn (The Jinn)

73. Al-Muzzammil (The One Covering Himself)

74. Al-Muddaththir (The One Wrapping Himself Up)

75. Al-Qiyāmah (The Resurrection)

76. Al-Insān (The Man)

77. Al-Mursalāt (Those Sent Forth)

78. An-Naba' (The Announcement)

79. An-Nazi'āt (Those Who Yearn)

80. 'Abasa (He Frowned)

81. At-Tatfif (The Folding Up)

82. Al-Infitār (The Cleaving)

83. At-Tatfiff (Default in Duty) 
84. Al-Inshiqāq (The Bursting Asunder)

85. Al-Burūj (The Stars)

86. At-Tāriq (The Comer by Night)

87. Al-'Alā' (The Most High)

88. Al-Ghashiyah (The Overwhelming Event)

89. Al-Fajr (The Daybreak)

90. Al-Balad (The City)

91. Ash-Shams (The Sun)

92. Al-Layl (The Night)

93. Ad-Duba (The Brightness of the Day)

94. Al-Inshirāh (The Expansion)

95. At-Tin (The Fig)

96. Al-'Alaq (The Clot)

97. Al-Qadr (The Majesty)

98. Al-Bayyinah (The Clear Evidence)

99. Al-Zilzal (The Shaking)

100. Al-'̄Adiyāt (The Assaulters)

101. Al-Q̄àriah (The Calamity)

102. At-Takāthur (The Abundance of Wealth)

103. Al-'Asr (The Time)

104. Al-Humazah (The Slanderer)

105. Al-Fīl (The Elephant)

106. Al-Quraish (The Quraish)

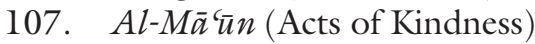

108. Al-Kauthar (The Abundance of Good)

109. Al-Käfirūn (The Disbelievers)

110. An-Nasr (The Help)

111. Al-Labab (The Flame)

112. Al-Ikblās (The Unity)

113. Al-Falaq (The Dawn)

114. An-Nās (The Men)

Glossary of Arabic Terms

$a d a b$

'adālah

'abd

'abd-Rabb civility; just action

justice

servant

servant-master 


\begin{tabular}{|c|c|}
\hline 'adl & justice; equilibrium \\
\hline al-Ghafür al-Rahìm & Ultimate Forgiver \\
\hline abādith & pl. words and actions of the Prophet \\
\hline al-Bashīr & Muhammad PBUH \\
\hline$a b k \bar{a} m$ & regulations \\
\hline akhlāq & virtuous conduct \\
\hline al-'Alìm & the most knowledgeable \\
\hline al-Bashir & the all-Seeing \\
\hline al-Hakìm & the most Wise \\
\hline al-Khāliq & the creator \\
\hline$a l-k i t \bar{a} b$ & the book \\
\hline$a l-m a^{\prime} \bar{a} d$ & eschatology \\
\hline amānah & trust \\
\hline$a l-n \bar{a} r$ & fire \\
\hline$a l-n \bar{a} s$ & humankind \\
\hline al-nubuwwah & prophethood \\
\hline al-qalb & heart \\
\hline al-Qādir & all-powerful \\
\hline al-sa' $\bar{a} d a t$ al-duny $\bar{a}$ & happiness in the present life \\
\hline al-sa'ādat al-quswa & supreme happiness \\
\hline al-Samī’i & the all-hearing \\
\hline$a l$-thawāb & reward \\
\hline al-thawāb wal-iqāb & reward and punishment \\
\hline al-wasatiyyah & moderation \\
\hline$a^{\prime} m \bar{a} l$ & good works \\
\hline amānab & honesty or trust \\
\hline 'aqīdah & creed \\
\hline 'aql & intellect \\
\hline 'aqli' & non-revealed \\
\hline al-sālihāt & good actions \\
\hline ashraf al-makblūqāt & noblest of creation \\
\hline asmāa-ul-husnā & the 99 names of Allah \\
\hline assalāmu álaykum & peace be unto you \\
\hline awliya $\bar{a}$ & partners \\
\hline $\bar{a} y \bar{a} t$ & signs, verses \\
\hline $\bar{a} y \bar{a} t$ bayyināt & clear signs \\
\hline birr & righteousness \\
\hline$d h i k r$ & to remember \\
\hline din al-fitrah & a religion of human nature \\
\hline
\end{tabular}




\begin{tabular}{|c|c|}
\hline fabm & understanding \\
\hline falsafa & philosophy \\
\hline fardh & obligatory acts \\
\hline fīabsan al-taqwīm & best of forms \\
\hline fitrah & to think \\
\hline fikriyyah & pondering on \\
\hline fiqh & jurisprudence \\
\hline fitnah & seditious speech \\
\hline fitrah & primordial human nature, purity \\
\hline ghībah & backbite \\
\hline badith & word/action of Prophet Muhammad PBUH \\
\hline hajj & pilgrimage \\
\hline Hanafiyya & named after Imam Abu Hanifa \\
\hline Hanbaliyya & named after Imam Ahmad ibn Hanbal \\
\hline haqq & truth and right \\
\hline harām & forbidden acts \\
\hline hijāb & head-scarf \\
\hline bikmah & wisdom \\
\hline bilm & forbearance \\
\hline budā & guidance \\
\hline hudāa al-nās & a guidance for humanity \\
\hline bukm & judgement \\
\hline 'ibādah & service to others \\
\hline$I b l i \bar{s}$ & Satan \\
\hline 'iffah & temperance \\
\hline$i \not h s \bar{a} n$ & perfection or excellence \\
\hline ikhtilāf & disagreement \\
\hline$i j m \bar{a}$, & consensus of opinion, mutual consultation \\
\hline ilm & knowledge \\
\hline$i j t i h \bar{a} d$ & independent, individual judgement \\
\hline ikhtilāf & diversity, pluralism, disagreement \\
\hline $\bar{\imath} m \bar{a} n$ billāh & belief in Allah \\
\hline $\bar{\imath} m \bar{a} n$ & faith \\
\hline insān & human being \\
\hline insān al-kāmil & perfect man \\
\hline Inshā Allah & God willing \\
\hline istighfār & forgiveness \\
\hline istibsān & judicial preference \\
\hline instinbāt & happiness \\
\hline$i^{\prime} t i d \bar{a} l$ & moderation \\
\hline
\end{tabular}




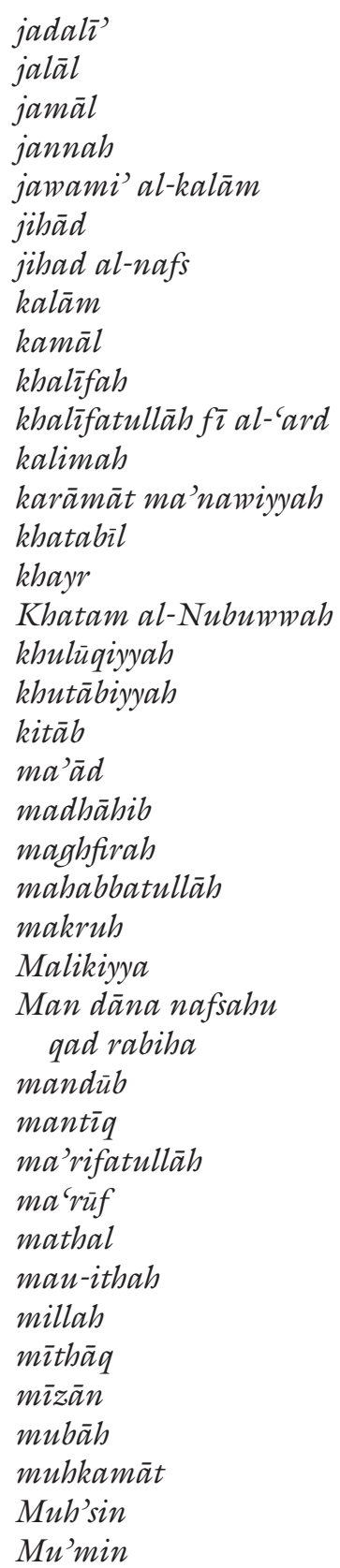

argumentative

infinite, divine majesty

beauty

paradise

high eloquence

struggle

inner struggles

word of Allah; scholastic theology

perfection

vicegerent on earth

a trustee of Allah on earth

proclamation or testimony of faith

moral marvels

poetic

goodness

seal of Prophethood

ethical

rhetoric

book

eschatology

schools of thought

forgiveness

love of Allah

reprehensible, but not forbidden

named after Imam Mālik ibn Anas

Whoever surrenders herself will

experience an increase in it

recommended acts

logic

knowledge of Allah

approved

pl. amthāl; parables

good instruction

religion

pact, covenant

balance

morally neutral acts

foundational or decisive

certifies the presence of God

worships God as if one can see Him 


\begin{tabular}{|c|c|}
\hline mushāf & compilation \\
\hline mutashābihāt & allegorical or unspecific \\
\hline$N a b \bar{\imath}$ & Prophet \\
\hline nafs & soul \\
\hline naqlì' & revealed \\
\hline$n \bar{a} r$ & fire \\
\hline$n \bar{a} s$ & humankind \\
\hline nazariyyah & theoretical \\
\hline$n i k \bar{a} b$ & face-covering \\
\hline ni'mah & Divine Favour \\
\hline nubuwwa & prophecy \\
\hline nisba & proportion \\
\hline nisyān & forgetfulness \\
\hline nutqiyyah & rational \\
\hline qalb & heart \\
\hline qist & equity \\
\hline qiyās & principles of analogy \\
\hline Qul hātū burhānakum & produce your evidence \\
\hline$\widetilde{q u} t b$ & universal being \\
\hline$R a b b$ & Lord \\
\hline rahmah & mercy, compassion \\
\hline Rasūl & Messenger \\
\hline rawiyyah & deliberation \\
\hline$r a^{\prime} y$ & rational argumentation \\
\hline rüh & spirit \\
\hline sakhā & generosity \\
\hline sajdah & prostration \\
\hline salāh & prayer, praying \\
\hline$s a b r$ & patience \\
\hline sālihāt & good actions \\
\hline sayyi' $\bar{a} t$ & bad actions \\
\hline Shäfi'yya & $\begin{array}{l}\text { named after Imam Abdullah Muhammad ibn } \\
\text { Idris al-Shāfici }\end{array}$ \\
\hline shahādah & the testimony \\
\hline shajā'ah & courage \\
\hline Shariah & Divine law \\
\hline shirk & ascribing a partner \\
\hline shukr & gratitude \\
\hline shūrē & mutual consultation, deliberative engagement \\
\hline
\end{tabular}




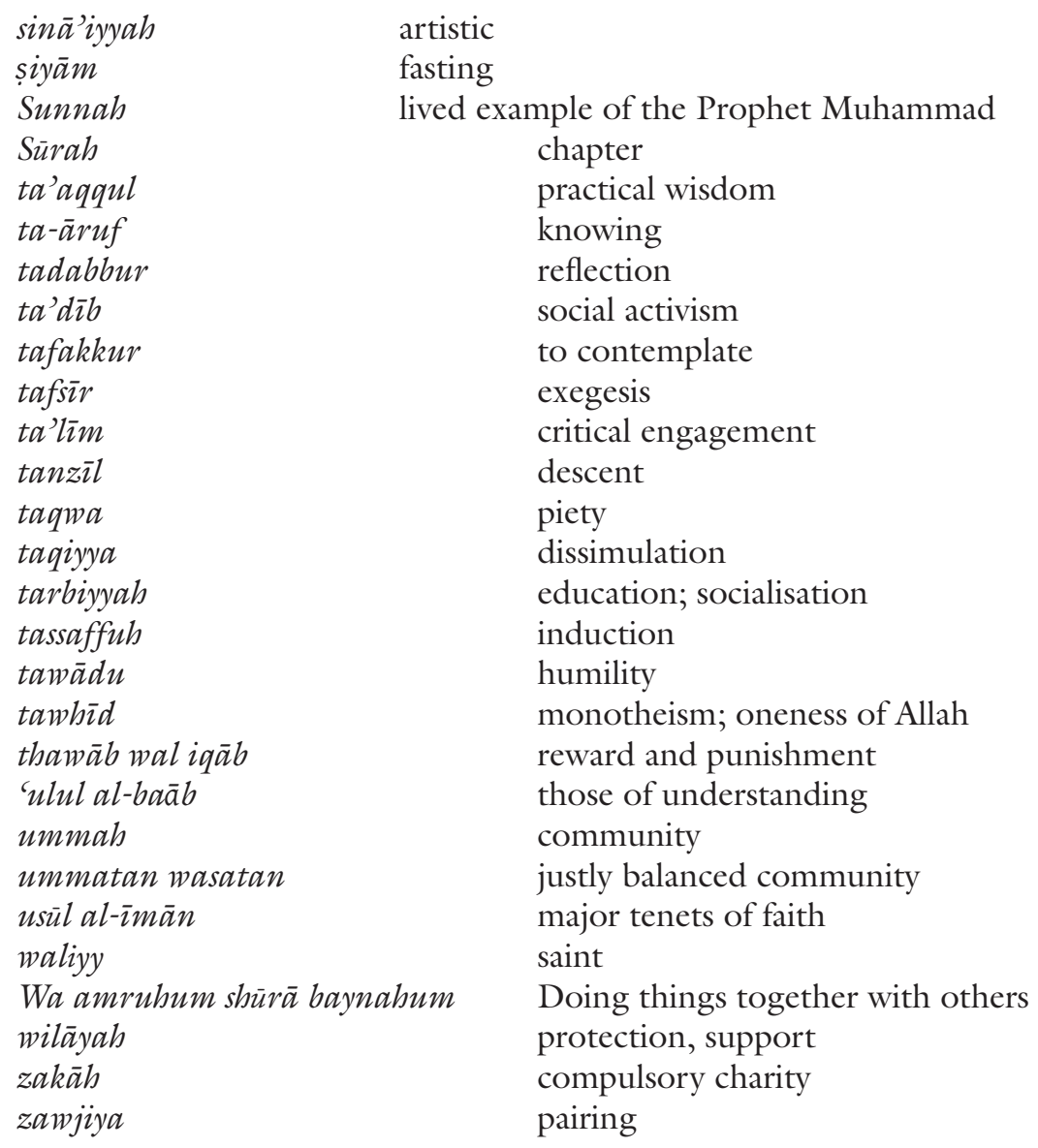

